\title{
Chronic Venous Insufficiency and Dystrophic Subcutaneous Calcification
}

\section{Insuficiência Venosa Crónica e Calcinose Cutânea Distrófica}

Sara CASTELO BRANCO $\rrbracket^{1}$, Mylene COSTA ${ }^{1}$, Alexandre VASCONCELOS ${ }^{1}$

Acta Med Port 2019 Feb;32(2):165-165 - https://doi.org/10.20344/amp.11110

Keywords: Calcinosis; Leg Ulcer; Venous Insufficiency

Palavras-chave: Calcinose; Insuficiência Venosa; Úlcera Perna

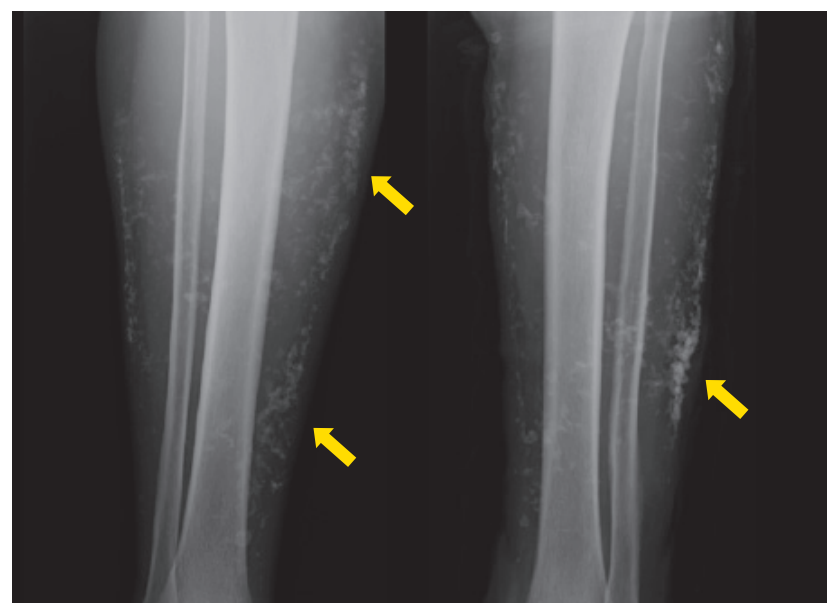

Figure 1 - Leg radiography showing subcutaneous calcification (arrows)

A 76-year old women was referred to the internal medicine department for subcutaneous calcifications on her legs (Fig. 1). She had a history of chronic venous insufficiency (CVI) of the lower extremities with chronic ulcerative lesions. The physical examination showed induration of the legs and subcutaneous white calcifications (Fig. 2). The patient had no other associated illnesses and had normal levels of parathyroid hormone, calcium, phosphorus, serum creatinine and 25-hydroxycholecalciferol. The immunological study for scleroderma, antiphospholipid

\section{PROTECTION OF HUMANS AND ANIMALS}

The authors declare that the procedures were followed according to the regulations established by the Clinical Research and Ethics Committee and to the Helsinki Declaration of the World Medical Association.

\section{DATA CONFIDENTIALITY}

The authors declare having followed the protocols in use at their working center regarding patients' data publication.

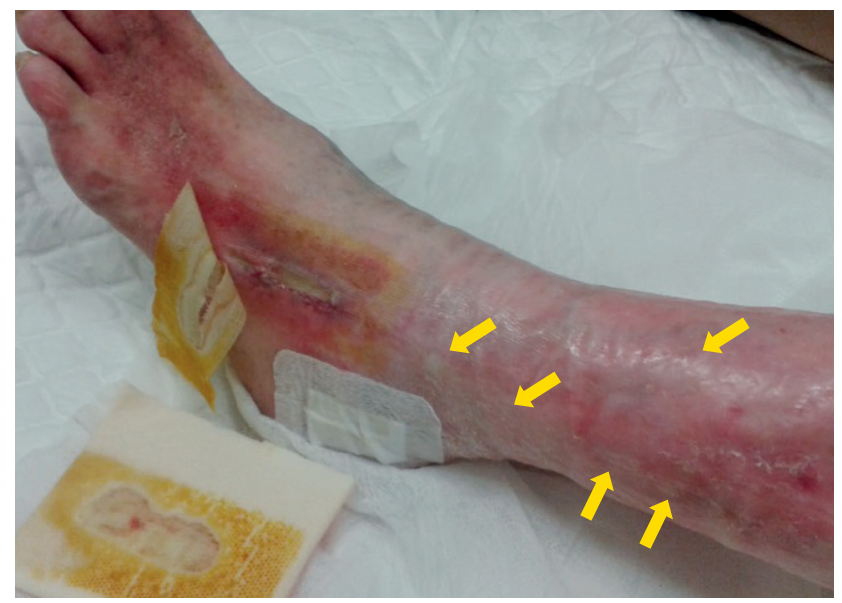

Figure 2 - Chronic ulcer with subcutaneous white calcifications (arrows)

antibodies and the serum cryoglobulins was normal. No evidence of neoplasm was found. CVI was confirmed on Doppler ultrasonography and the histological examination of the ulcer showed dysmorphic calcification. CVI promotes the deposition of calcium phosphate in the tissues. ${ }^{1,2}$ Calcium deposits cause persistent inflammatory reaction and lead to leg ulcer recurrences which increase the risk of further calcium salt deposition. ${ }^{3,4}$ Our patient underwent analgesic treatment and started hyperbaric oxygen therapy with clinical improvement.

\section{INFORMED CONSENT \\ Obtained.}

\section{CONFLICTS OF INTEREST}

All authors report no conflict of interest.

\section{FUNDING SOURCES}

This research received no specific grant from any funding agency in the public, commercial, or not-for-profit sectors.

\section{REFERENCES}

1. Chave TA, Varma S, Knight AG. Dystrophic calcinosis cutis in venous ulcers: a cause of treatment failure. Br J Dermatol. 2001;145:364-5.

2. Miedinger D, Daikeler T. Images in clinical medicine. Chronic venous insufficiency and dystrophic subcutaneous calcification. N Engl J Med. 2008;358:e10.

3. Wollina U, Hasenöhrl K, Köstler E, Schönlebe J, Heinig B, Haroske G, et al. Dystrophic calcification in chronic leg ulcers - a clinicopathologic study. Dermatol Surg. 2009;35:457-61.

4. Tokoro S, Satoh T, Okubo Y, Igawa K, Yokozeki H. Latent dystrophic subcutaneous calcification in patients with chronic venous insufficiency. Acta Derm Venereol. 2009;89:505-8.

1. Serviço de Medicina Interna. Hospital Pedro Hispano. Matosinhos. Portugal.

$\triangle$ Autor correspondente: Sara Castelo Branco. sara.castellobranco@gmail.com

Recebido: 23 de julho de 2018 - Aceite: 21 de setembro de 2018| Copyright @ Ordem dos Médicos 2019 